\title{
Destination Image, Satisfaction and Tourist Loyalty: A Study of Post Disaster Recovery in Gili Matra
}

\author{
Dwi Putra Buana Sakti ${ }^{1, *}$, Siti Nurmayanti ${ }^{2} \&$ M. Firmansyah ${ }^{3}$
}

\author{
${ }^{1}$ University of Mataram, Mataram, Indonesia \\ ${ }^{2}$ University of Mataram, Mataram, Indonesia \\ ${ }^{3}$ University of Mataram, Mataram, Indonesia \\ *Corresponding author. Email: dwiputrabs@unram.ac.id
}

\begin{abstract}
This study analyzes the mediation role of destination image on the influence of tourist satisfaction toward loyalty according to the survey on 155 sample respondents who visited Gili Matra after the 2018 earthquake. A structural equation model (SEM) was used to analyze the collected data. The research findings reveal that tourist destinations' cognitive and affective image has a significant effect on tourist satisfaction. Furthermore, tourist satisfaction is shown to mediate the influence of destination image on tourist satisfaction significantly. In addition, this research also outlines the theoretical and managerial implications regarding risk management and promotion strategies for risky destinations.
\end{abstract}

Keywords: destination image, satisfaction, loyalty.

\section{INTRODUCTION}

Tourism is a service industry characterized by intangible products that are vulnerable to various risks such as crime, political instability, natural disasters, disease outbreaks, terrorism, and others. Threats that may occur in a particular tourist destination can tarnish the image of the tourist destination (Sönmez et al. 1999). If it has happened, it will be difficult for a tourist to evaluate the attractiveness of a tourist destination since their decision to visit tends to be based on perception than reality (Kim \& Richardson 2003). With that, Lehto et al. (2008) state that the tourists' perceived risk is one of the critical determinants that influences their travel decisions.

--The reality in Japan shows that domestic and foreign tourists generally worried about travel risks after the Fukushima disaster in 2011. After the disaster ended, tourists were still concerned about the risk of radia- tion exposure through contaminated food, water, and air. At that time, the Japanese tourism authorities had to strive to restore the image of Japan as a safe tourist destination to maintain the number of tourist visits in the following years.

Several studies had been conducted to examine the visitors' perception of the risk and tourism destination image about decision making and travel behavior (Lepp et al. 2011, Qu et al. 2009). Those studies were conducted to follow up with Qi et al. (2009), who suggest integrating the risks and tourist destinations in a study. Therefore, separating the two kinds of tourist destination image in research is needed to know the risk perceived by visitor and tourist destination image as separate constructs in one integrated study.

Some empirical evidence shows that tourists are willing to revisit the tourist destinations even though they are aware of the risks (Li et al. 2010, Rittichainuwat \& Chakrabor 
ty 2009). The willingness to revisit occurs because the local tourism authorities are successful in overcoming the risks. Furthermore, previous travel experience, travel motivation, loyalty, age, nationality, and cultural aspects are the conditions that make them revisit the risky tourist destination (Fuchs \& Reichel 2011, Glaesser 2003, Reichel et al. 2007, Rittichainuwat 2006, Rittichainuwat \& Chakraborty 2012). Returning tourists tend to act like reference groups and informal advertising channels by word of mouth (WOM), which effectively disseminates information (Chi \& Qu 2008).

\section{RESEARCH METHODS}

This research is a confirmatory study aimed at examining the role of tourist destination image in mediating the effect of risk perceived by tourists on revisit intention. The research target population was domestic tourists over 17 years who visited Lombok Island after the earthquake in July until September 2018. The data was collected through a survey, and it was carried out for five months from June to October 2019. There were 150 tourists for the research sample. Non-probability sampling designed was used as a sample design. In a non-probability sampling design, each member of the population did not have the same opportunity to be selected as a sample. The sampling technique used was purposive sampling. The purposive sampling technique means that population members can be assigned as samples if they meet the characteristics of the population member and appropriate with the research objectives. The questionnaire in this study consisted of five parts. The first part was related to the respondent's perception of physical risk. The second part itemized the respondent's perception of financial risk. The third part described the respondent's perception of cognitive image, while the fourth part expressed the respondent's perception of an effective image. Last, the fifth part revealed the respondent's perception of revisit intention.
Physical and financial risk perception is measured using a risk scale developed by Fuchs \& Reichel (2004, 2006). The scales were measured using a five-point Likert scale item ranging from (1) Strongly disagree to (5) Strongly agree. An example of a physical risk perception statement is "I am worried about natural disasters in Lombok Island after the earthquake of 7 SR".

Likewise, financial risk is measured with a five-point Likert scale item ranging from (1) Strongly disagree to (5) Strongly agree. The example of the statement is "I am afraid that traveling to Lombok Island after the earthquake of 7 SR will burden me financially than other tourist destinations in Indonesia".

The cognitive image in this study adopts thirteen attributes of the cognitive scale of Baloglu \& McCleary (1999) that are relevant to the research context. This scale was measured using a five-point Likert scale item ranging from (1) Strongly Disagree (5) Strongly Agree. An example of the statement used is "the accommodation available in Lombok island is suitable". The affective image was measured using a four-item bipolar Likert scale developed by Russell \& Pratt (1980).

Revisit intention was measured by adopting a scale developed by Huang \& Hsu (2009) using a five-point Likert scale ranging from (1) Strongly Disagree to (5) Strongly Agree). The example of the statement is "I intend to revisit Lombok Island in the next one year as a travel destination".

After completing the questions, the next step was to conduct a validation test through the try out on 30 students of the Halal Tourism Study Program in Master of Management, Faculty of Economics and Business, University of Mataram. The validation test was conducted to investigate whether the respondent understood each item of the statement and whether the order of statements in the questionnaire was suitable for the respondent's answer. Data collection was carried out directly without prior notification to tourists at the research location to get valid 
and reliable respondents. The hypotheses proposed were tested by SEM analysis.

\section{RESULTS AND DISCUSSIONS}

Table 1 exhibits the results of path analysis in destination image variable on tourist satisfaction variable and also tourist loyalty variable.

Table 1. The Results of the Path

\begin{tabular}{|c|c|c|c|c|}
\hline $\begin{array}{l}\text { Predictor } \\
\text { Variable }\end{array}$ & $\begin{array}{l}\text { Criterion } \\
\text { Variable }\end{array}$ & CR & $\begin{array}{l}\text { Std. Co- } \\
\text { eff. }\end{array}$ & R2 \\
\hline $\begin{array}{l}\text { Tourist Des- } \\
\text { tination Im- } \\
\text { age }\end{array}$ & $\begin{array}{l}\text { Tourist } \\
\text { satisfac- } \\
\text { tion }\end{array}$ & 3.204 & $0.837 * *$ & \\
\hline $\begin{array}{l}\text { Tourist Des- } \\
\text { tination Im- } \\
\text { age }\end{array}$ & $\begin{array}{l}\text { Tourist } \\
\text { Loyalty }\end{array}$ & 3.038 & $0.260 * *$ & 0.720 \\
\hline $\begin{array}{l}\text { Tourist satis- } \\
\text { faction }\end{array}$ & $\begin{array}{l}\text { Tourist } \\
\text { Loyalty }\end{array}$ & 2.800 & $0.652^{* *}$ & \\
\hline
\end{tabular}

\begin{tabular}{|c|c|c|}
\hline Statistics & $\begin{array}{l}\text { Recom- } \\
\text { mended }\end{array}$ & Results \\
\hline The significance of Chi-squared & $\geq 0.05$ & 6.228 \\
\hline Goodness Fit of Index (GFI) & $\geq 0.90$ & 0.997 \\
\hline $\begin{array}{l}\text { Adjusted Goodness of Fit Index } \\
\text { (AGFI) }\end{array}$ & $\geq 0.80$ & 0.970 \\
\hline Comparative Fit Index (CFI) & $\geq 0.90$ & 0.998 \\
\hline Normed Fit Index (NFI) & $\geq 0.90$ & 0.997 \\
\hline $\begin{array}{l}\text { The Root Mean Square Error of Ap- } \\
\text { proximation (RMSEA) }\end{array}$ & $\geq 0.08$ & 0.008 \\
\hline
\end{tabular}

Source: Processed data (2021)

The influence of Gili Matra's image as an island tourist destination on tourist loyalty is shown by a Beta coefficient of 0.732 , T value is 11.311 with a probability of 0.000 (p $<0.05)$. Based on this probability value, the proposed hypothesis is supported, so it must be accepted.

Beta coefficient, which shows the influence of tourist destination image on tourist loyalty variable, is 0,293 , with a value of 3,706 and a probability of $0,000(\mathrm{p}<0,005)$. Referring to that, the proposed hypothesis has supported, so it must be accepted. The significance of the tourist satisfaction variable on tourist loyalty is indicated by the Beta coefficient value of 0,585 , value 7,389, and probability $0.000(\mathrm{p}<0.005)$. Based on these results, the proposed hypothesis is supported, then it must be accepted.

The results of this study indicate that the direct effect of destination image on tourist loyalty is 0.293 . Meanwhile, the calculation of the indirect effect of destination image variable on tourist loyalty variable through tourist satisfaction variable is 0.428 . The total effect is 0.721 . Figure 1 exhibits the results of path analysis of destination image $(\mathrm{X})$, tourist satisfaction (Y1), and tourist loyalty (Y2).

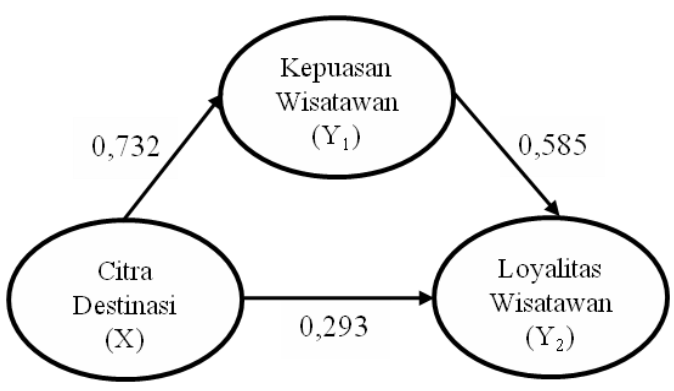

Figure 1. Path Analysis Results

Referring to the results above, it can be seen that the indirect effect has a bigger effect than the direct effect with a value of 0.428 or $42.8 \%$. It shows that the positive image of Gili Matra as a halal tourist destination can generate stronger loyalty if the visitors are satisfied. Tourists with positive knowledge (cognitive aspect) and feel a good experience (affection aspect) on Gili Matra can get high satisfaction, leading to loyalty. This loyalty leads them to recommend to others, say positive things, and/or revisit in the future.

This study confirms the relationship between perceived travel risk (physical, sociopsychological and financial risk) and destination images (cognitive and active images). There are relatively few studies examine the role of perceived travel risk in shaping the image of a tourist destination (Lehto et al. 2008, Lepp et al. 2011), even though a deeper understanding of the relationship of this concept is needed (Qi et al. 2009, Sönmez 1998).

When the three risk types were examined together, it is found that socio-psychological and financial risk are relevant to revisit in- 
tention to Lombok island after an earthquake. This study proves that cognitive and affective image are significant variables that mediate the influence of socio-psychological and financial risk on the revisit intention.

This study reveals that sociopsychological and financial risk have a significant effect on cognitive and affective images of tourist destinations. Tourists are most likely to return to Lombok Island, which is affected by socio-psychological and financial risks, by reconstructing the tourist destination's cognitive and affective images. Furthermore, this study proves that physical risk does not affect tourist destinations' cognitive and affective images.

The insignificant effect of physical risk on cognitive and affective images of tourist destinations in this study can be caused by personal factors (age, marital status, psychological values, motivation) and stimulus factors (experiences from previous trips and intimate among tourists). Both factors mentioned previously can influence the perceived risk (Beerli \& Martin 2004; Fuchs \& Reichel 2011) and tourist destination which is formed (Baloglu 2000, Baloglu \& McCleary 1999, Beerli \& Martin 2004). The previous travel experience to Lombok Island before the earthquake has fostered a strong image of Lombok Island as a tourist destination with beautiful beaches, white sand, a paradise for diving, and so on.

Tourists with revisit experience tend to trust their experience more and their logical and emotional interpretations to shape the image of a tourist destination. Therefore, in this study, the physical risk does not affect Lombok Island's cognitive or affective image as their destination. In addition, tourists who will visit Lombok Island after the earthquake have received information from various sources regarding the safe condition of tourism infrastructure. The findings of this study also indicate the rate of visitors dealing with the physical risk. The low physical risk might be faced by tourists when visiting Lombok Island after the earthquake. Meanwhile, on the other hand, their revisit intention to Lombok Island after the earthquake was relatively high.

\section{CONCLUSION}

This research analyzes destination image, tourist satisfaction, and loyalty in the context of the recovery period of Gili Matra after the earthquake. The main focus of this research is to examine the role of tourist destination image mediation on the effect of satisfaction on tourist loyalty in the case of Gili Matra's recovery after the earthquake.

Overall, the findings of this study show that (i) The image of Gili Matra as an island tourist destination affects the tourist's satisfaction; (ii) The image of Gili Matra as an island tourist destination affects tourist loyalty in the form of recommending it to family, friends, others, and the desire to revisit; and (iii) Tourist satisfaction affects their loyalty.

As a popular destination, Gili Matra must increase the infrastructure quality and quantity, the quality of tourism service, natural resources, and varied entertainment that must be adjusted to tourist expectations. To gain tourist loyalty, Gili Matra should create an ambiance that makes tourists feel relax, happy, and cheerful during their visit.

To manage these emotional elements, traditional means of building infrastructure, quality service provision, and diversified entertainment offerings are still insufficient. These can be considered absolute requirements, but apart from that, the tourist industry must coordinate to suit the tourist needs.

Gili Matra tourism stakeholders still need to analyze the efforts to ensure that tourists who visit Gili Matra get a positive affective image. The tourists will revisit Gili Matra through this positive affective image. If Gili Matra stakeholders can create loyal tourists, it will contribute to the economy of the West Nusa Tenggara region in general and economic and employment opportunities for the surrounding communities. 


\section{REFERENCES}

Baloglu, S. \& McCleary, K.W. 1999. A model of destination image formation. Annals of Tourism Research 26(4): 868-897.

Baloglu, S. 2000. A path analytic model of visitation intention involving information sources, sociopsychological motivations, and destination image. Journal of Travel \& Tourism Marketing 8(3): 8190.

Beerli, A. \& Martin, J.D. 2004. Factors influencing destination image. Annals of Tourism Research 31(3): 657-681.

Chi, C.G.Q. \& Qu, H. 2008. Examining the structural relationships of destination image, tourist satisfaction and destination loyalty: an integrated approach. Tourism Management 29(4): 624-636.

Fuchs, G. \& Reichel, A. 2004. Cultural differences in tourist destination risk perception: an exploratory study. Tourism: An International Interdisciplinary Journal 52(1): 21-37.

Fuchs, G. \& Reichel, A. 2006. Tourist destination risk perception: the case of Israel. Journal of Hospitality \& Leisure Marketing 14(2): 83-108.

Fuchs, G. \& Reichel, A. 2011. An exploratory inquiry into destination risk perceptions and risk reduction strategies of first-time vs. repeat visitors to a highly volatile destination. Tourism Management 32(2): 266-276.

Glaesser, D. 2003. Crisis management in the tourism industry. Amsterdam: Butterworth Heinemann.

Huang, S. \& Hsu, C.H. 2009. Effects of travel motivation, experience, perceived constraint, and attitude on revisit intention. Journal of Travel Research 48(1): 29-44.

Kim, H. \& Richardson, S.L. 2003. Motion picture impacts destination images. Annals of Tourism Research 30(1): 216-237.

Lehto, X., Douglas, A.C. \& Park, J. 2008. Mediating the effects of natural disasters on travel intention. Journal of Travel \& Tourism Marketing 23(2/3/4): 29-43.

Lepp, A., Gibson, H. \& Lane, C. 2011. Image and perceived risk: a study of Uganda and its official tourism website. Tourism Management 32(3): 675-684.

Li, M., Cai, L.A., Lehto, X.Y. \& Huang, Z. 2010. A missing link in understanding revisits intention $\mathrm{e}$ the role of motivation and image. Journal of Travel \& Tourism Marketing 27(4): 335-348.

Qi, C.X., Gibson, H.J. \& Zhang, J.J. 2009. Perceptions of risk and travel intentions: the case of China and the Beijing Olympic Games. Journal of Sport \& Tourism 14(1): 43-67.

Qu, H., Kim, L.H. \& Im, H. H. (2011). A model of destination branding: integrating the concepts of the branding and destination image. Tourism Management, 32(3), 465e476.
Reichel, A., Fuchs, G. \& Uriely, N. 2007. Perceived risk and the noninstitutionalized tourist role: the case of Israeli student ex-backpackers. Journal of Travel Research 46(2), 217-226.

Rittichainuwat, B.N. 2006. Tsunami recovery: a case study of Thailand's tourism. Cornell Hotel \& Restaurant Administration Quarterly 47(4): 390-404.

Rittichainuwat, B.N. \& Chakraborty, G. 2009. Perceived travel risks regarding terrorism and disease: the case of Thailand. Tourism Management 30(3): 410-418.

Rittichainuwat, B.N. \& Chakraborty, G. 2012. Perceptions of importance and what safety is enough. Journal of Business Research 65(1): 42-50.

Russell, J. A. \& Pratt, G. (1980). A description of the affective quality attributed to environments. Journal of Personality \& Social Psychology 38(2): 311-322.

Sönmez, S. F. 1998. Tourism, terrorism, and political instability. Annals of Tourism Research 25(2): 416-456.

Sönmez, S.F., Apostolopoulos, Y. \& Tarlow, P. 1999. Tourism in crisis: managing the effects of terrorism. Journal of Travel Research 38(1): 13-18. 